\title{
Marginal contribution of game statistics to probability of playing playoff at elite basketball leagues
}

\author{
Contribución marginal de las estadísticas del juego a la probabilidad de jugar \\ los playoffs en las ligas de baloncesto de élite
}

\author{
José M. Izquierdo' ${ }^{1}$, Luis E. Pedauga² ${ }^{2}$ Ana Pardo-Fanjul ${ }^{2}$, Juan C. Redondo ${ }^{1}$ \\ 1 Department of Physical Education and Sports, Faculty of Physical Activity and Sports Sciences; University of León, España. \\ 2 Department of Economics and Statistics. University of León, España.
}

CORRESPONDENCIA:

José María Izquierdo Velasco

jizqv@unileon.es

Recepción: octubre 2020 • Aceptación: febrero 2021
CÓMO CITAR EL ARTÍCULO:

Izquierdo, J. M., Pedauga, L. E., Pardo-Fanjul, A., \& Redondo, J. C. (2021). Marginal contribution of game statistics to probability of playing playoff at elite basketball leagues. Cultura, Ciencia y Deporte, 16(49), 433-442. http://dx.doi.org/10.12800/ccd. v16i49.1586

\begin{abstract}
The multilevel ordinal logistic mixed-effects method applied is proposed as a support tool to management in basketball teams helping to identify the game-related statistics that discriminate the final ranking in a regular season classification. A sample of 10684 games that cover 10 seasons and reach sample of 752 cases were evaluated from the two main Spanish basketball leagues (male and female). The multilevel analysis applied identifies the marginal effects of the main variables regularly evaluated by coaches and managers in basketball leagues, which may help them improve the performance of their teams. The results revealed that in Relegation zone the marginal contribution of field shots, defensive rebound, steals and turnovers percentage are 8.3 percentage points ( $\mathrm{pp}), 7 \mathrm{pp}, 9.6 \mathrm{pp}$ and $8.6 \mathrm{pp}$ respectively, higher than in Play-off zone $(p<0.01)$. The model applied in this study make a significant contribution to the literature by identifying a methodology that can be straightforwardly extended for an assessment at the ranking of teams helping coaches in making important decisions such as hierarchically discriminating which factors are the most relevant in their league, both to avoid the relegation zone and to access the promotion zone.
\end{abstract}

Key words: basketball, performance analysis, gamerelated statistics, sport analytics.

\section{Resumen}

La aplicación del análisis multinivel de efectos mixtos logísticos ordinales se muestra como una herramienta de apoyo a la gestión del baloncesto para identificar las estadísticas de juego que discriminan la posición final en la clasificación en temporada regular. Se tomaron datos de 10684 partidos que abarcan 10 temporadas y alcanzan la muestra de 752 casos de las dos principales ligas españolas (masculino y femenino). El análisis multinivel aplicado, identifica los efectos marginales de principales variables evaluadas por los entrenadores de baloncesto, que pueden ayudarles a mejorar el rendimiento de sus equipos. Los resultados muestran que, para los equipos localizados en la zona de descenso, la contribución marginal de los porcentajes de tiros de campo, rebote defensivo, robos y pérdidas de balón fue de 8,3 puntos porcentuales (pp), 7 pp, 9,6 pp y 8,6 pp respectivamente, mayor que en los equipos en zona de Play-off $(p<0,01)$. El modelo aplicado aporta una contribución significativa a la literatura al identificar una metodología que puede extenderse directamente para una evaluación en el puesto clasificatorio de los equipos, ayudando de esta manera a los entrenadores a tomar decisiones importantes, como discriminar jerárquicamente qué factores son los más relevantes, tanto para evitar la zona de descenso y acceder a la zona de playoff.

Palabras clave: baloncesto, análisis de rendimiento, estadísticas de juego, análisis deportivo. 


\section{Introduction}

Sports teams today's use the amount data available to their advantage. The sports industry uses sports analysis to increase revenue (Bradbury, 2019) and the availability of the economical resources (GarcíaManso et al., 2020), improve player performance (Gutiérrez \& Ruiz, 2013), a team's quality of play (Sampaio et al., 2004), and win games (Utku, 2016) and tournaments (Sáenz-López et al., 2017), prevent injuries (Glasgow \& Mutch, 2019) and for many more enhancements. Further, the data is beneficial to many in the industry including coaches, managers, agents, scouts, marketing professionals, medical personnel and the analytics staff. The sport world is multivariate: data are collected simultaneously on many variables (which are typically strongly related to each other), often across space and time. In order to appropriately analyze such data, their structured multivariate nature (and their associated uncertainty) must be modelled correctly. Thus, visualizing and modelling such data in an appropriate statistical manner is the key to making good data-driven decisions. In this sense, analyzing elite sports performance data and supporting decision making that is essential to increasing success (Ofoghi et al., 2013).

Basketball is a data rich game which has many actions and factors to analyze (Gómez et al., 2006). Basketball, as a team sport, is characterized by the execution by each of the players a series of skills in multiple situations during the development of the game, producing a non-linearity, a chaotic behavior and an interconnection of processes and events. There has been a continuous review of the concepts since the Money-ball phenomenon (Lewis, 2004), arising from the playing field and outside, as well as better information analysis techniques that offer valuable data for managers and players taking decisions. Inferential statistics can yield very detailed and important information to consumers of professional basketball. Moreover, inferential statistics can be used to determine factors that predict the performance levels of teams (Onwuegbuzie, 2000). The need for positive results takes to use management tools that estimate athletic performance of professional players reliable in regards to the decision by the sport managers, for example, when they are designing the player roster (Salmerón-Gómez \& Gómez-Haro, 2016).

Throughout a match, there are a lot of possible decisions that can be taken, which depend on the characteristics of players, their previous experience. More detailed understanding of statistics demands (field shots percentage, steals, blocks...) and other game-related areas can augment player-centered decision making, leading to enhanced player care, and improved team performance. These actions can be classified according to a certain character, for example, in defensive and offensive actions; so, the chances of success are varied (Gómez et al., 2007a; Gutiérrez \& Ruiz, 2013). In this sense, to optimize the outcome of a team, it is necessary to consider the degree of mastery of the game at the collective level, the performance of each player, and the relationships with teammates and opponents. So, we have a complex system of variables that are hard to control in their entirety. So, author as Salmerón-Gómez et al (2016) has studied the way of measuring the individual performance of players and developing reliable instruments to assess and quantify personal outcomes in professional basketball.

But is the coach who must facilitate the conditions to develop player's skills and tactical model aimed to obtain the best efficiency and effectiveness possible in the game (Trninić et al., 2009). Thus, it becomes necessary to know the appropriate levels of performance of each player matching their skills and possibilities according to the type and characteristics of each competition (Paulauskas et al., 2018; GarcíaUnanue et al., 2014). Consequently, the study of the keys to sports success in a team remains an absolute necessity, especially when the winner is not the favorite (Sáenz-López et al., 2017).

Therefore, with the match statistics analysis the coach could find the keys to the results of his team. Basketball is one of the team sports that has traditionally used game statistics to know the performance of the competition (Gómez et al., 2007b). So, in order to differentiating the winning teams from losers, some investigations have documented the importance of defensive rebounds (Ibáñez et al., 2009; Madarame, 2017), of the two-point-field goal percentage (Ibáñez et al., 2009; Madarame, 2017; Puente et al., 2015), the three-point-field goal percentage, the assists (Ibáñez et al., 2009; Madarame, 2017; Puente et al., 2015), steals and turnovers (Utku, 2016; İlkay et al., 2016).

In this perspective, it is observed that several studies have estimated the contribution of basketball actions on winning probability by calculating the marginal contribution of producing one unit more of an action than the opponent. Furthermore, there are other studies comparing regular season versus Playoffs separately for a single season or comparing two different leagues but in none of that kind of studies look for relating the variables analyzed to the probability to improve the ranking in any particular league. In this framework, our primary hypothesis focuses on 
detecting the marginal effect of performance actions at different leagues because the results may help coaches to determine at which area more effort should be directed at each stage of the competition.

\section{Methodology}

\section{Data sources and variables}

The data cover the team level statistics of each team in every league game played during ten seasons (2009/10 until 2018/19) and it was retrieved from two official sources: the Spanish Basketball Federation (www.feb.com) and the National Basketball Association (www.acb.com). With regard these seasons a total of 10684 games are involved. The compilation of the sample was based on the average for each team in every season

In summary, the data cover 10 seasons, reaching a sample of 752 cases (Table 1 ) by the two professional women's categories: Women's League 1 (LF1) and Women's League 2 (LF2), as well as in the two men's categories: Association League of Basketball Clubs (ACB) and Spanish Gold Basketball League (LEB).

This study was not subject to specific approval by any ethics committee of the institutions involved. There were collected public domain data that did not require any formal approbation by an institution. The study was, however, conducted in accordance with the Declaration of Helsinki.

Table 1. Sample distribution according to gender and type of league: Seasons 2009/10 to 2018/19

\begin{tabular}{lccc}
\hline League & Gender & Matches & Sample \\
\hline ACB - First League & \multirow{2}{*}{ Male } & 3010 & 179 \\
\cline { 1 - 1 } & & 2636 & 167 \\
\hline LEB - Second League & \multirow{2}{*}{ Female } & 1688 & 135 \\
\cline { 1 - 1 } \cline { 3 - 4 } LF2 - Second League & & 3350 & 271 \\
\hline & Total & $\mathbf{1 0 6 8 4}$ & $\mathbf{7 5 2}$ \\
\hline
\end{tabular}

Source: Spanish Basketball Federation and National Basketball Association.

The collected data allow us to describe the ranking position of professional basketball team categories on a sample that covering ten seasons from 2009/20 to 2018/19 conditional to several game-related statistics, showed in Table 2, according to official sources (Spanish Basketball Federation and National Basketball Association). All this, to be able to predict the positions of the teams in classification zones in each season.

Regarding the predictors variables, although we have a database that contains a total of 16 game statistics, we considered just the following eights: Fields shot,
Offensive rebounds, Defensive rebounds, Steals, Turnovers, Blocks received, Blocks made and Fault committed to faults received. As can be seen in the descriptive analysis of the data (table 3 ), there is a high correlation between different groups of variables (panels A, B, and C). To mitigate the potential threat of multicollinearity between predictor variables, the decision strategy to exempt this group of variables was based on ruling out those that had a lower correlation with respect to the dependent variable, leaving only those that did not present collinearity risks.

Table 2. Game related variables. Mean per match.

\begin{tabular}{l}
\hline \multicolumn{1}{c}{ Name of Variable } \\
\hline Ranking position: First place to last place \\
\hline Field shots percentage (\%) \\
\hline Two points \% \\
\hline Three points \% \\
\hline Points per game \\
\hline Assists \\
\hline All rebounds \\
\hline Offensive rebounds \\
\hline Defensive rebounds \\
\hline Steals \\
\hline Turnovers \\
\hline Blocks received \\
\hline Blocks made \\
\hline Fault committed \\
\hline Faults received \\
\hline Fault committed to faults received \\
\hline
\end{tabular}

Multilevel ordinal logistic mixed-effects method

In order to describe variation among teams in the probability of classification position a multilevel ordinal logistic mixed-effects model was specified. The dependent variable, ranking, is expected to be conditional on a set of predictors variables based on the game-related statistics measured throughout the classification in the main Spanish Basketball Federation, pooled together with female and male level categories, covering ten consecutive regular seasons.

In a multilevel analysis, sometimes also called a hierarchical, random coefficient or mixed-effect model, the data structure in the population is hierarchical, and data are viewed as a multistage sample from this hierarchical population (Goldstein, 2003). Consequently, teams are hierarchical nested in a four-level model that relates the dependent variable to predictor variables at more than one level (Luke, 2004). In descending order, the level-4 contains the 
ten seasons of the professional Spanish Basketball dataset; there are two leagues at the level-3 (male and female); each of these leagues composed of two different categories conforming level-2. Finally, the teams assumed to be randomly made up level-1.

The selection of a multilevel estimation approach is based in the fact that the teams do not necessarily constitute a panel survey, given that a team from one season cannot be necessarily tracked in another season, and the estimations through a pooled estimation makes unfeasible the distinction between temporal or sampling effects. In this sense, the panel element in the sample if any, is treated using multilevel estimation approach, where a generalized ordinal fourlevel model was estimated in terms of the cumulative comparisons of the ordinal dependent variable $Y_{i j t}$ conditional to the independent variable $X_{i j l t}$. Formally, following Hedeker \& Gibbons (1994), the cumulative probabilities for the $K$ categories of the ordinal dependent variable $Y$ was defined as:

$$
P_{i j l t}^{(k)}=\operatorname{Prob}\left(Y_{i j l t} \leq k\right)=\sum_{k=1}^{K} p_{i j l t}^{(k)}
$$

where $p_{i j l t}^{(k)}$ denote the individual category probabilities. In this sense, the mixed-effects ordered regression model for the cumulative probabilities was assumed to have a logistic distribution. Denoting with $\lambda_{i j l t}^{(k)}(K=1, \ldots, K-1)$ a cumulative ordinal logistic link function as ${ }^{24}$ was specified as:

$$
\lambda_{i j l t}^{(k)}=\operatorname{logit}\left[\frac{P_{i j l t}^{(k)}}{1-P_{i j l t}^{(k)}}\right]=\gamma_{i}^{(k)}-\left[x_{i j l t}^{\prime} \beta+\varepsilon_{j l t}\right]
$$

where $i$ is the team level-1, $i$ is the categories level-2, $i$ is the league level- 3 and $t$ serves to index the season level-4. Dependent variable $Y_{i j l t}$ gathers ranking position. The explanatory variables, which were previously described, are presented by $X_{i j l t}$. Finally, $\varepsilon_{j t l}$ is an error term, that in hierarchical model, consists of three components:

$$
\varepsilon_{j t l}=v_{j l t}+\mu_{\cdot l t}+v_{\cdot \cdot l}
$$

The population distribution of these random effects is usually assumed to be a normal distribution with zero mean and constant variance, $v_{j l t} \sim N\left(0, \sigma_{v}^{2}\right)$, $\mu_{\cdot l t} \sim N\left(0, \sigma_{\mu}^{2}\right), v_{\cdot \cdot l} \sim N\left(0, \sigma_{v}^{2}\right)$, accounting for unobserved heterogeneity at different levels of the hierarchy. As noted by Srholec (2010), the presence of more than one residual term makes standards multivariate models such as fixed-effects specification inapplicable, and, therefore, generalized maximum likelihood (GML) procedures should be used to estimate these models properly. Finally, each of $K-1$ logit expresses the ratio between the probability to ranking category $k$ or lower of team $i$ in category $j$ in the league $l$ in season $t$ on the probability to rank higher position as function of a $K-1$ strictly increasing model thresholds $\gamma_{i}^{(k)}$ (i.e., $\gamma^{(1)}<$ $\left.\gamma^{(2)}<\ldots<\gamma^{(\mathrm{K}-1)}\right)$.

For the purpose of study, the estimated log odds ratios parameters $ß$ are presented and their sign and significance discussed. Since the log odds ratios in ordinal logistic regression are not comparable across models due to unobserved heterogeneity and difficult to interpret, results from multinomial ordinal regression models allows us to recover the marginal effects of explanatory variables on unconditional probabilities and conditional probabilities (Gelman \& Pardoe, 2007; Harrell, 2001)

The marginal effects for the latter probabilities are somewhat easier to interpret. These shown the change in probability when the independent variable increases by one unit, holding the others constant at their mean. For all analyses, a p-value under 0.05 was considered statistically significant. In order to gain interpretation of these results, the positions in the final ranking of each season were reduced to four levels: i) Play-off, ii) Next to play-off, iii) Next to relegation and iv) Relegation zones. Since the final purpose of the teams could be considered dual: play to win the league or promote to a higher category or play to avoid relegation. In this sense "Play-off" and "Relegation zone" would be the main levels which in turn enable two secondary levels next to them: "Next to play-off" and "Next to relegation".

\section{Results}

As can be notice from the descriptive statistic (Table 3 ), there is a high correlation between different groups of variables (panels $A, B$, and $C$ ). In this sense, to avoid bias in the variance due to high multicollinearity between these variables, four similar specifications were made, using in each of them the measurements separately along with the other explanatory variables. Regardless the model specification used, the variables: Defensive rebounds, Steals, Turnovers, Blocks received, Blocks made ant the ratio Fault committed to faults received were significant in all models. Only Offensive rebounds and Blocks received variables where founded not significant when the model use the free throws as an independent variable.

The multilevel ordinal logistic mixed-effects method when considering as explanatory variable the position obtained by each team at the end of each season (first 
Table 3. Descriptive Statistics and Correlation. Values are presented as mean per game.

\begin{tabular}{|c|c|c|c|c|c|c|c|c|c|c|c|c|c|c|c|c|c|c|c|c|c|}
\hline & Variables & Mean & SD & Min & $\operatorname{Max}$ & 1 & 2 & 3 & 4 & 5 & 6 & 7 & 8 & 9 & 10 & 11 & 12 & 13 & 14 & 15 & 16 \\
\hline 1. & $\begin{array}{l}\text { Ranking position: First } \\
\text { place to last place }\end{array}$ & 8.185 & 4.609 & 1.000 & 18.000 & & & & & & & & & & & & & & & & \\
\hline 2. & $\begin{array}{l}\text { Hit in: Field shots } \\
\text { percentage }(\%)\end{array}$ & 42.62 & 3.74 & 32.03 & 53.28 & $-0.312^{*}$ & & & & & & & & & & & & & & & \\
\hline 3. & Two points \% & 47.60 & 4.73 & 34.96 & 60.12 & $-0.244^{*}$ & $0.960^{*}$ & & & & & & & & & & & & & & \\
\hline 4. & Three points $\%$ & 32.52 & 3.76 & 20.05 & 42.96 & $-0.286^{*}$ & $0.801^{*}$ & $0.700^{*}$ & & & & & & & & & & & & & \\
\hline 5. & Free throws \% & 71.37 & 5.08 & 49.73 & 83.33 & $-0.067^{*}$ & $0.566^{*}$ & $0.558^{*}$ & $0.562^{*}$ & $-A$ & & & & & & & & & & & \\
\hline 6. & Points per game & 70.68 & 7.85 & 47.92 & 94.09 & $-0.268^{*}$ & $0.896^{*}$ & $0.900^{*}$ & $0.771^{*}$ & $0.623^{*}$ & & & & & & & & & & & \\
\hline 7. & Assists & 12.48 & 2.62 & 5.42 & 20.77 & $-0.278^{*}$ & $0.751^{*}$ & $0.767^{*}$ & $0.632^{*}$ & $0.491^{*}$ & $0.787^{*}$ & & & & & & & & & & \\
\hline 8. & All rebounds & 33.12 & 2.70 & 23.74 & 44.04 & $-0.394^{*}$ & 0.131 & 0.113 & 0.021 & -0.008 & $0.270^{*}$ & $0.289^{*}$ & & & & & & & & & \\
\hline 9. & Offensive rebounds & 9.81 & 1.43 & 5.23 & 15.42 & $-0.185^{*}$ & -0.017 & -0.012 & -0.074 & -0.071 & $0.189^{*}$ & 0.089 & $0.732^{*}$ & - B - & & & & & & & \\
\hline 10. & Defensive rebounds & 23.31 & 1.92 & 16.67 & 29.59 & $-0.417^{*}$ & $0.196^{*}$ & $0.167^{*}$ & 0.085 & 0.042 & $0.240^{*}$ & $0.341^{*}$ & $0.861^{*}$ & $0.284^{*}$ & & & & & & & \\
\hline 11. & Steals & 7.98 & 1.42 & 4.77 & 12.73 & $-0.332^{*}$ & $-0.131^{*}$ & $-0.180^{*}$ & $-0.197^{*}$ & $-0.237^{*}$ & $-0.145^{*}$ & -0.089 & 0.076 & $0.225^{*}$ & -0.061 & & & & & & \\
\hline 12. & Turnovers & 14.60 & 1.96 & 8.62 & 24.46 & $0.084^{*}$ & $-0.433^{*}$ & $-0.495^{*}$ & $-0.440^{*}$ & $-0.419^{*}$ & $-0.574^{*}$ & $-0.463^{*}$ & 0.049 & 0.060 & 0.024 & $0.307^{*}$ & & & & & \\
\hline 13. & Blocks received & 2.10 & 0.68 & 0.38 & 4.77 & $-0.088^{*}$ & $0.383^{*}$ & $0.399^{*}$ & $0.282^{*}$ & $0.221^{*}$ & $0.439^{*}$ & $0.396^{*}$ & $0.280^{*}$ & $0.196^{*}$ & $0.247^{*}$ & -0.019 & $-0.181^{*}$ & & & & \\
\hline 14. & Blocks made & 1.95 & 0.59 & 0.50 & 3.94 & $0.313^{*}$ & $0.199^{*}$ & $0.226^{*}$ & $0.193^{*}$ & $0.290^{*}$ & $0.306^{*}$ & $0.282^{*}$ & -0.035 & 0.073 & -0.103 & $-0.211^{*}$ & $-0.189^{\star}$ & 0.208 & & & \\
\hline 15. & Fault committed & 18.66 & 2.25 & 13.00 & 26.03 & $0.231^{*}$ & 0.345 & 0.421 & 0.322 & 0.332 & $0.465^{*}$ & $0.343^{*}$ & -0.077 & 0.115 & -0.194 & $-0.158^{*}$ & $-0.249^{*}$ & $0.236^{*}$ & $0.392^{*}$ & & \\
\hline 16. & Faults received & 18.54 & 2.03 & 12.42 & 23.82 & $0.078^{*}$ & 0.493 & 0.552 & 0.413 & 0.416 & $0.641^{*}$ & $0.437^{*}$ & 0.135 & $0.206^{*}$ & 0.037 & $-0.236^{*}$ & $-0.311^{*}$ & $0.319^{*}$ & $0.431^{*}$ & $0.620^{*}$ & - C - \\
\hline 17. & $\begin{array}{l}\text { Fault committed to } \\
\text { faults received }\end{array}$ & 1.01 & 0.10 & 0.71 & 1.41 & $0.188^{*}$ & $-0.135^{*}$ & $-0.109^{*}$ & -0.074 & -0.067 & $-0.151^{*}$ & -0.074 & $-0.241^{*}$ & -0.085 & $-0.275^{*}$ & 0.075 & 0.044 & -0.068 & -0.010 & $0.508^{*}$ & $-0.354^{*}$ \\
\hline
\end{tabular}

Table 4. Multilevel ordinal logistic mixed-effects method. Dependent variable: Ranking position (First to last position).

\begin{tabular}{|c|c|c|c|c|c|c|c|c|}
\hline \multirow{2}{*}{$\begin{array}{l}\text { Variables } \\
\text { Hit in: Field shots }\end{array}$} & \multicolumn{2}{|c|}{$\begin{array}{c}\text { Model A } \\
\text { Coef. }\end{array}$} & \multicolumn{2}{|c|}{$\begin{array}{c}\text { Model B } \\
\text { Coef. }\end{array}$} & \multicolumn{2}{|c|}{$\begin{array}{c}\text { Model C } \\
\text { Coef. }\end{array}$} & \multicolumn{2}{|c|}{$\begin{array}{l}\text { Model D } \\
\text { Coef. }\end{array}$} \\
\hline & $\begin{array}{l}-0.220 \\
(0.022)\end{array}$ & $* * *$ & & & & & & \\
\hline Two points & & & $\begin{array}{l}-0.251 \\
(0.022)\end{array}$ & $* * *$ & & & & \\
\hline Three points & & & & & $\begin{array}{l}-0.144 \\
(0.017)\end{array}$ & $* * *$ & & \\
\hline Free throws & & & & & & & $\begin{array}{l}-0.063 \\
(0.014)\end{array}$ & \\
\hline Offensive rebounds & $\begin{array}{l}-0.091 \\
(0.049)\end{array}$ & * & $\begin{array}{l}-0.097 \\
(0.049)\end{array}$ & ** & $\begin{array}{l}-0.064 \\
(0.048)\end{array}$ & & $\begin{array}{l}-0.045 \\
(0.049)\end{array}$ & \\
\hline Defensive rebounds & $\begin{array}{l}-0.458 \\
(0.043)\end{array}$ & $* * *$ & $\begin{array}{l}-0.510 \\
(0.044)\end{array}$ & $* * *$ & $\begin{array}{l}-0.465 \\
(0.044)\end{array}$ & *** & $\begin{array}{l}-0.514 \\
(0.047)\end{array}$ & *** \\
\hline Steals & $\begin{array}{l}-0.654 \\
(0.055)\end{array}$ & $* * *$ & $\begin{array}{l}-0.734 \\
(0.056)\end{array}$ & $* * *$ & $\begin{array}{l}-0.695 \\
(0.055)\end{array}$ & $* * *$ & $\begin{array}{l}-0.682 \\
(0.055)\end{array}$ & $* * *$ \\
\hline Turnovers & $\begin{array}{c}0.155 \\
(0.041)\end{array}$ & $* * *$ & $\begin{array}{c}0.147 \\
(0.040)\end{array}$ & $* * *$ & $\begin{array}{c}0.199 \\
(0.042)\end{array}$ & $* * *$ & $\begin{array}{c}0.277 \\
(0.042)\end{array}$ & $* * *$ \\
\hline Blocks received & $\begin{array}{c}0.281 \\
(0.111)\end{array}$ & ** & $\begin{array}{c}0.215 \\
(0.108)\end{array}$ & ** & $\begin{array}{c}0.254 \\
(0.111)\end{array}$ & ** & $\begin{array}{c}0.043 \\
(0.107)\end{array}$ & \\
\hline Blocks made & $\begin{array}{c}1.096 \\
(0.125)\end{array}$ & $* * *$ & $\begin{array}{c}1.146 \\
(0.127)\end{array}$ & $* * *$ & $\begin{array}{c}1.078 \\
(0.126) \\
\end{array}$ & $* * *$ & $\begin{array}{c}1.002 \\
(0.127) \\
\end{array}$ & *** \\
\hline Fault committed to faults received & $\begin{array}{c}2.086 \\
(0.638)\end{array}$ & $* * *$ & $\begin{array}{c}2.273 \\
(0.638)\end{array}$ & $* * *$ & $\begin{array}{c}2.380 \\
(0.638)\end{array}$ & $* * *$ & $\begin{array}{c}2.189 \\
(0.638)\end{array}$ & $\star * *$ \\
\hline Observation & 752 & & 752 & & 752 & & 752 & \\
\hline Seasons & 10 & & 10 & & 10 & & 10 & \\
\hline Leagues & 3 & & 3 & & 3 & & 3 & \\
\hline Log likelihood & -1872.06 & & -1851.40 & & -1886.22 & & -1911.37 & \\
\hline$\chi^{2}$ & 0.39 & & 1.55 & * & 1.49 & & 2.92 & $\star *$ \\
\hline
\end{tabular}

Notes: Standard errors in parentheses. ${ }^{*} p<0.1,{ }^{* *} p<0.05,{ }^{* * *} p<0.01$ 
Table 5. Multilevel ordinal logistic mixed-effects method. Dependent variable Play-off (1), Next to play-off (2), Next to relegation (3) and Relegation (4).

\begin{tabular}{|c|c|c|c|c|c|c|c|c|c|c|}
\hline \multirow{4}{*}{$\begin{array}{l}\text { Variables } \\
\text { Field shots }\end{array}$} & & & \multicolumn{8}{|c|}{ Marginal Effects at Variable Means (MEM) } \\
\hline & \multicolumn{2}{|c|}{ Regression results } & \multicolumn{2}{|c|}{ Play-off } & \multirow{2}{*}{\multicolumn{2}{|c|}{$\begin{array}{c}\text { Next to play-off } \\
\mathrm{dx} / \mathrm{dy}\end{array}$}} & \multirow{2}{*}{\multicolumn{2}{|c|}{$\begin{array}{c}\text { Next to relegation } \\
d x / d y\end{array}$}} & \multirow{2}{*}{\multicolumn{2}{|c|}{$\begin{array}{c}\text { Relegation zones } \\
\mathrm{dx} / \mathrm{dy}\end{array}$}} \\
\hline & \multicolumn{2}{|c|}{ Coef } & \multicolumn{2}{|c|}{$d x / d y$} & & & & & & \\
\hline & $\begin{array}{l}-0.310 \\
(0.028)\end{array}$ & $* * *$ & $\begin{array}{c}0.059 \\
(0.005)\end{array}$ & $* * *$ & $\begin{array}{l}-0.017 \\
(0.004)\end{array}$ & $* * *$ & \multicolumn{2}{|l|}{-0.030} & $\begin{array}{l}-0.011 \\
(0.001)\end{array}$ & $* * *$ \\
\hline Offensive rebounds & $\begin{array}{l}-0.149 \\
(0.058)\end{array}$ & ** & $\begin{array}{l}0.024 \\
(0.009)\end{array}$ & $* *$ & $\begin{array}{l}-0.002 \\
(0.001)\end{array}$ & & $\begin{array}{l}-0.011 \\
(0.005)\end{array}$ & ** & $\begin{array}{l}-0.010 \\
(0.004)\end{array}$ & $* * *$ \\
\hline Defensive rebounds & $\begin{array}{l}-0.411 \\
(0.053)\end{array}$ & $* * *$ & $\begin{array}{c}0.069 \\
(0.009)\end{array}$ & $* * *$ & $\begin{array}{l}-0.003 \\
(0.002)\end{array}$ & & $\begin{array}{l}-0.036 \\
(0.005)\end{array}$ & $* * *$ & $\begin{array}{l}-0.030 \\
(0.004)\end{array}$ & $* * *$ \\
\hline Steals & $\begin{array}{l}-0.572 \\
(0.067)\end{array}$ & $* * *$ & $\begin{array}{c}0.092 \\
(0.010)\end{array}$ & $* * *$ & $\begin{array}{l}-0.021 \\
(0.004)\end{array}$ & $* * *$ & $\begin{array}{l}-0.042 \\
(0.005)\end{array}$ & $* * *$ & $\begin{array}{l}-0.029 \\
(0.003)\end{array}$ & $* * *$ \\
\hline Turnovers & $\begin{array}{c}0.270 \\
(0.052)\end{array}$ & $* * *$ & $\begin{array}{l}-0.042 \\
(0.008)\end{array}$ & $* * *$ & $\begin{array}{l}0.000 \\
(0.002)\end{array}$ & & $\begin{array}{c}0.022 \\
(0.005)\end{array}$ & *** & $\begin{array}{l}0.020 \\
(0.004)\end{array}$ & $* * *$ \\
\hline Blocks received & $\begin{array}{c}0.131 \\
(0.127)\end{array}$ & & $\begin{array}{l}-0.020 \\
(0.019)\end{array}$ & & $\begin{array}{c}0.001 \\
(0.001)\end{array}$ & & $\begin{array}{l}0.010 \\
(0.009)\end{array}$ & & $\begin{array}{c}0.009 \\
(0.009)\end{array}$ & \\
\hline Blocks made & $\begin{array}{c}0.718 \\
(0.145)\end{array}$ & $* * *$ & $\begin{array}{l}-0.114 \\
(0.022)\end{array}$ & $* * *$ & $\begin{array}{c}0.009 \\
(0.004)\end{array}$ & ** & $\begin{array}{l}0.054 \\
(0.011)\end{array}$ & $* * *$ & $\begin{array}{c}0.051 \\
(0.011)\end{array}$ & $* * *$ \\
\hline $\begin{array}{l}\text { Fault committed to } \\
\text { faults received }\end{array}$ & $\begin{array}{c}1.721 \\
(0.721)\end{array}$ & ** & $\begin{array}{l}-0.272 \\
(0.115)\end{array}$ & $* *$ & $\begin{array}{c}0.019 \\
(0.012)\end{array}$ & & $\begin{array}{l}0.133 \\
(0.058)\end{array}$ & ** & $\begin{array}{c}0.121 \\
(0.050)\end{array}$ & ** \\
\hline Observation & 752 & & 752 & & 752 & & 752 & & 752 & \\
\hline Seasons & 3 & & 3 & & 3 & & 3 & & 3 & \\
\hline Leagues & 10 & & 10 & & 10 & & 10 & & 10 & \\
\hline Log likelihood & 760.58 & & & & & & & & & \\
\hline$\chi^{2}$ & 6.63 & $* *$ & & & & & & & & \\
\hline
\end{tabular}

position, rank $=1$, to last position, rank = ranging 11 to 18) are presented in Table 4. In this table, the fitted models along with the estimated effects and their standard errors are summarized. This specification allows knowing in terms of likelihood the independent variables that can determine the correct strategy in terms of the position of each team. Therefore, likelihood ratio tests were conducted to test the overall effect of each independent variable on the model. Independent variables that had an overall significant effect $(p<0.05)$ were subsequently considered as significant. The estimated odds ratio shows the chance in odds of being in one of the ranking position of the dependent variable. An important feature of the multivariate ordinal logistic regression is that it estimates $\mathrm{k}-1$ models, where $\mathrm{k}$ is the number of levels of the outcome variable.

These results are shown in the first column of Table 5. Additionally, the marginal effects ( $\mathrm{dx} / \mathrm{dy})$ at variable means (MEM) are presented in the last four columns and represented in Figure 1. As mentioned previously, this is done for the purpose of facilitating the interpretation of the results. These shown the change in probability when the independent variable increases by one unit, holding the others constant at their mean. In this context, multilevel ordinal logistic mixed-effects model revealed that the highest marginal effects, expressed in percentage points (pp) were located in Defensive rebounds (6.9 pp), Steals (-2.1 pp), Blocks made (5.4 pp) and Blocks made (5.1 pp) regarding to Play-off, Next to play-off, Next to relegation and Relegation zones, respectively. For all analyses, a p-value under 0.05 was considered statistically significant.

\section{Discussion}

In this regard, we tried to identify the marginal contribution of each statistic to discriminate the final ranking in the regular basketball season by employing a strategy that enables the correct measurement of the relative effects. We have also considered how the effects change with the level of competition considering the ranking of the teams in four groups: play-off, next to play-off, next to relegation and relegation zones in the ranking. In addition to reporting expected contributions of game statistics to increase in a final ranking, this study points to striking results at higher or lower levels of competition. 


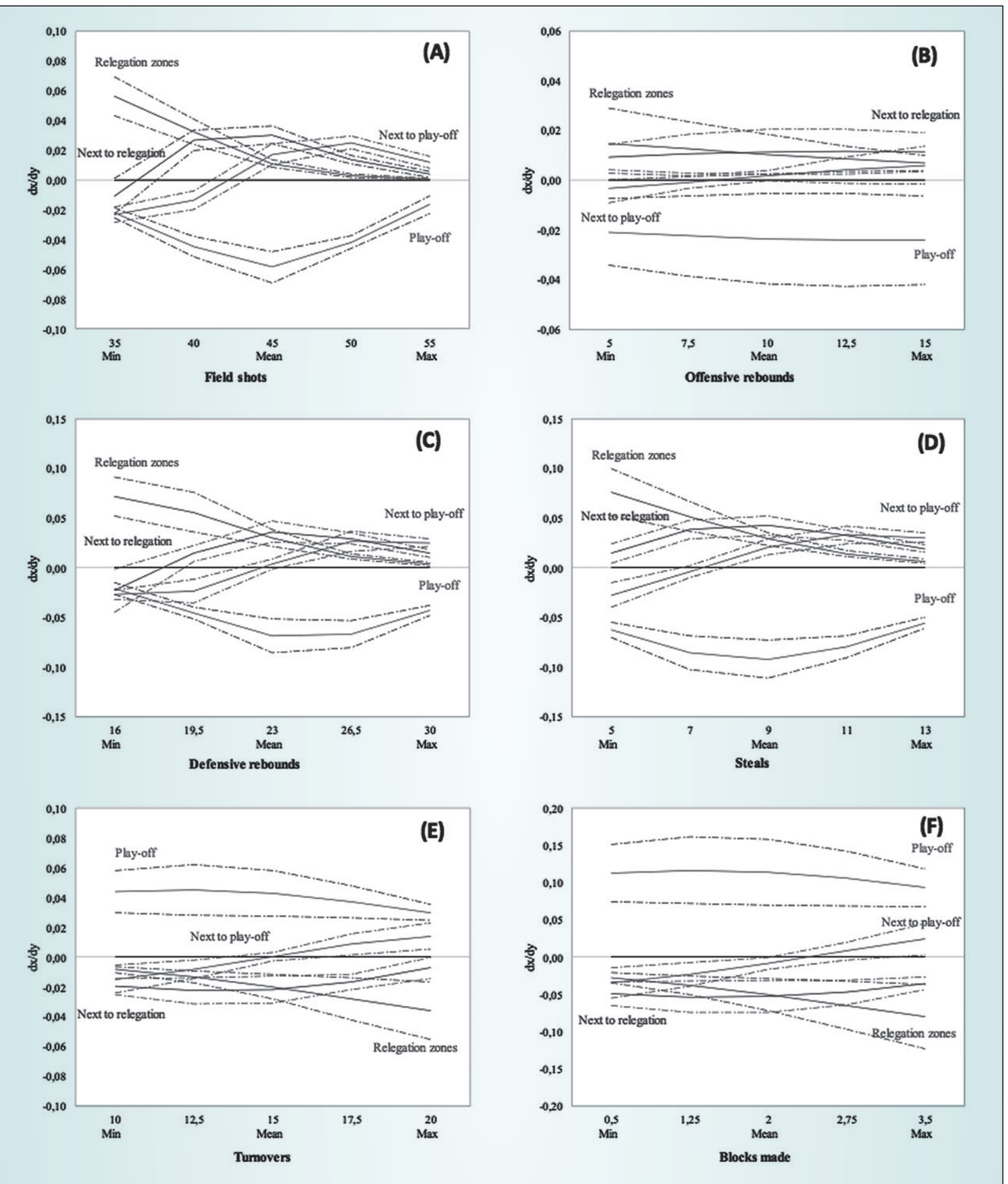

Figure 1. Analysis of the Predictive Marginal Effects of game-related statistics. Dashed lines signify $95 \%$ confidence intervals. (A) Field shots; (B) Offensive rebounds; (C) Defensive rebounds; (D) Steals; (E) Turnovers; (F) Blocks made; dx/dy = marginal effect.

We have observed that relative importance of several factors increases dramatically depending if a team is located in high or low zone in the ranking. In this regard, our model revealed that in Relegation zone the marginal contribution of field shots percentage is 8.3 (pp) higher than in Play-off zone. Achieving a percentage of 55 hits or more per game increases 6 pp the chances to leave the Relegation zone. In fact, successful offences have the goal of selecting carefully field-goal opportunities and are dependent upon the quality of player's decisionmaking and field-goal execution as well as upon team coordination (Sampaio et al., 2004). It seems clear that these actions are directly related to assist skill in women (Gómez et al., 2009; Sáenz-López et al., 2017) 
and men (Pojskić et al., 2009). We could suggest that a very important training time should be directed to tasks that integrate perceptual, decision, and motor components to improve the ability to pass.

Using game statistics and determining the factors that differentiate winner and loser teams based on discriminant analysis, the typical conclusion of studies of this sort showed that winning teams grab more defensive rebounds, have a higher shooting percentage and assist than losing teams. In our study, defensive rebounds showed $7 \mathrm{pp}$ of marginal contribution higher in Relegation zone than of in Play-off zone. Defensive rebounding is a key part of good defense in general, limiting the offense to just one shot. Results from other researches show how defensive rebounds affect team success (Gómez et al., 2008; Navarro et al., 2009; Pojskić et al., 2009).

Results evident that defensive rebounds are linked to the possibility of winning, since each time this fact occurs, it requires that the opposing team fails the shot; Therefore, it has been correlated with the percentage of field shots (Oliver, 2004). This difference decreases when the percentage of field shots is quite similar between the 2 teams. In addition, defensive rebounding combined with a quick outlet pass can be an effective offensive weapon, getting the transition game and fast break going, for a lay-up at the other end.

Likewise, the marginal contribution effect of offensive rebounds are $3 \mathrm{pp}$ higher in Next to relegation and Relegation zone than Play-off zone. Offensive rebounding should be a very important part of your team offense in general and also it is a good way to pick up extra easy baskets. In this sense, it can be considered very frustrating to the defender when the opponent gets several offensive rebounds for more shots at the hoop, until it finally to score. Good rebounders have an attitude, a mind-set, that every rebound is theirs and are very aggressive on the boards, moreover, the technique to capture these rebounds is important. Winning the inside position by blocking the opponent, leaving him behind us, will give us a lot of advantage. The general importance of the rebounds has led various preparers to prepare video sessions to evaluate and prepare the players to guess the direction of the ball after the failed throws (Lampert-Ribas et al., 2011).

Steals are a very significant predictor related to other box score stats. Our results showed the importance of this variable for all teams in all analyzed categories. Both for the teams located in the relegation zone or near it, as well as the teams that intend to get into the play-off zone. Our study reveals that the marginal contribution effect of steals are $9.6 \mathrm{pp}$ higher in relegation zone than Play-off zone. This skill has already been related to success in women of the first US league (Gómez et al., 2009) and in men in the second Spanish league (Ibáñez et al., 2008). For this reason, it could be the statistic from the common box score to tell as much as possible about whether a player helps or hurts his team, it is not how many points to score, nor how many rebounds to grab, nor how many assists to dishes out. It is how many steals he or she gets.

However, the marginal contribution of turnovers is $8.6 \mathrm{pp}$ in Relegation zone higher than Play-off zone. Therefore, it is not uncommon to see terribly high turnover numbers from teams located in a lower zone un the table or in teams that feature from new players who don't have a lot of experience playing in professional leagues. This is in line which have been observed on studies for Europe (Utku, 2016), USA (Rimler et al., 2010; Teramoto \& Cross, 2010) and world championships (Sampaio et al., 2004). Turnovers are important because a team cannot even shoot, never mind score, if it turns over the ball during a possession. This case is expected when someone makes a bad pass or just dribbles out of bounds or travels.

Blocks received has a difference of $23 \mathrm{pp}$ in Play-off respect to Relegation zone. So, this ability is a major aspect in teams located in the top positions in the table. In the second Spanish league is demonstrated the influence of this variable in the top teams (Ibáñez et al., 2008). A well player with the ability to block shots can be a positive asset to a team's defense, as they can make it difficult for opposing players to shoot near the basket and by keeping the basketball in play, as opposed to swatting it out of bounds, a blocked shot can lead to a fast break.

Likewise, the effect of faults can reach up to 71 pp in Play-off compared to Relegation zone. But it is remarkable the difference between Next to relegation and Relegation zones (22.4 pp). The fouls are the enemy of the effective defense. Moreover, a good field shots percentage will help you cut down your opponent's fast break opportunities, which allows your defense to get set and cut down on personal fouls. In this sense, committing a high number of fouls in the game is something characteristic of lower level teams (Gómez et al., 2009; Ibáñez et al., 2003; Sampaio \& Janeira, 2003).

\section{Conclusions}

The multilevel ordinal logistic mixed-effects method applied have been shown as support tools for the management of basketball to identify the game-related statistics that discriminated the final 
ranking in the regular season classification. These methodologies provide coaches and managers with a thorough knowledge of their teams by pointing to a sharp increase in the marginal contribution of producing best specifics stats of various game factors along the season. However, further studies that focus on specific leagues are needed to obtain more reliable specific models.

As an important feature of this methodology we would like to point out that the model obtained has taken into consideration the main variables regularly evaluated by coaches and managers in basketball leagues, which may help them improve the performance of their teams. The key issue is that different variables may have different ways to achieve the efficiency on the ranking. The marginal contribution evaluation allows to ranking the variables by means of an estimated odds ratio in which each one is assessed with respect to the patterns of game that other teams have used in their play.

In this sense, the results of this study make a significant contribution to the literature by identifying a model that can be straightforwardly extended for an assessment at the ranking of teams helping coaches in making important decisions such as hierarchically discriminating which factors are the most relevant in their league, both to avoid the relegation zone and to access the promotion zone.

\section{REFERENCES}

Bradbury, J. C. (2019). Determinants of revenue in sports leagues: An empirical assessment. Economic Inquiry, 57(1), 121-140. https://doi. org/10.1111/ecin.12710

García, J., Ibáñez, S. J., \& Feu, S. (2010). Game statistics that discriminate the national teams partipating in the 2006 World Basketball Championship, regarding the level and the gender of the teams. Kronos, 9(17), 57-63.

García-Manso, J. M., Arriaza, A., Martínez-González, J. M., RamosVerde, E., Díaz-Díaz, R., \& García-Roca, J. A. (2020). What makes Elite Leagues Profesional? Cultura, Ciencia y Deporte, 15(45), 303-311. https://doi.org/10.12800/ccd.v15i45.1508

García-Unanue, J., Godoy, A., Villarrubia, L., Sanchez-Sanchez, J., \& Gallardo, L. (2014). Competitive balance in European basketball leagues and the NBA. Cultura, Ciencia y Deporte, 9(27), 235-242. http://dx.doi.org/10.12800/ccd.v9i27.465

Gelman, A., \& Pardoe, I. (2007). Average predictive comparisons for models with nonlinearity, interactions, and variance components. Sociological Methodology, 37(1), 23-51. doi: https://doi.org/10.1111/ j.1467-9531.2007.00181.x

Glasgow, P., \& Mutch, S. (2019). Twists, Turns \& Entanglement - Complexity and the tricky challenges of sport for the athlete and practitioner. British Journal of Sports Medicine, 53(19), 1197-1197. https://doi.org/10.1136/ bjsports-2019-101518

Goldstein, H. (2003). Multilevel modelling of educational data Methodology and epistemology of multilevel analysis (pp. 25-42): Springer.

Gómez, M., Lorenzo, A., Ortega, E., Sampaio, J., \& Ibáñez, S. (2009). Game related statistics discriminating between starters and nonstarters players in Women's National Basketball Association League (WNBA). Journal of Sports Science and Medicine, 8(2), 278.

Gómez, M., Lorenzo, A., Sampaio, J., Ibáñez, S., \& Ortega, E. (2008). Game-related statistics that discriminated winning and losing teams from the Spanish men's professional basketball teams. Collegium Antropologicum, 32(2), 451-456.

Gómez, M. A., Lorenzo, A., Ortega, E., Sampaio, J., \& Ibanez, S. J. (2007). Difference between women's basketball guards, forwards and centres through game related statistics. Cultura, Ciencia y Deporte, 2(6), 139144. http://dx.doi.org/10.12800/ccd.v2i6.182

Gómez, M. A., Lorenzo, A., Ortega, E., \& Olmedilla, A. (2007). Differences in the performance indicators of winning and losing women's basketball teams during home/away games. Revista de psicología del deporte, 16(1), 41-54.

Gómez, M. A., Lorenzo, A., Sampaio, J., \& Ibáñez, S. J. (2006). Differences in game-related statistics between winning and losing teams in women's basketball. Journal of Human Movement Studies, 51, 357-369.

Gutiérrez, Ó., \& Ruiz, J. L. (2013). Data envelopment analysis and cross-efficiency evaluation in the management of sports teams: the assessment of game performance of players in the Spanish handball league. Journal of Sport Management, 27(3), 217-229. https://doi. org/10.1123/jsm.27.3.217

Harrell, F. (2001). Regression Modeling Strategies, with Applications to Linear Models, Survival Analysis and Logistic Regression: New York, NY, Springer.

Hedeker, D., \& Gibbons, R. D. (1994). A random-effects ordinal regression model for multilevel analysis. Biometrics, 50(4), 933-944. https://doi. org $/ 10.2307 / 2533433$

Ibáñez, S., Sampaio, J., Feu, S., Lorenzo, A., Gómez, M., \& Ortega, E. (2008). Basketball game-related statistics that discriminate between teams' season-long success. European Journal of Sport Sciences, 8(6), 369-372. https://doi.org/10.1080/17461390802261470

Ibáñez, S., Sampaio, J., Sáenz-López, P., Giménez, J., \& Janeira, M. (2003). Game statistics discriminating the final outcome of junior world basketball championship matches (Portugal 1999). Journal of Human Movement Studies, 45(1), 1-20.

Ibáñez, S. J., García, J., Feu, S., Lorenzo, A., \& Sampaio, J. (2009). Effects of consecutive basketball games on the game-related statistics that discriminate winner and losing teams. Journal of Sports Science and Medicine, 8(3), 458-462.

İlkay, I., Işik, O., \& Ersöz , Y. (2016). Examining the turkish men's professional basketball team's success according to game-related statistics with discriminant analysis. International Journal of Performance and Analysis in Sport, 16(3). https://doi.org/10.1080/24748668.2016.1 1868931

Lampert Ribas, R., Navarro, R., Tavares, F., \& Gómez, M. (2011). Analysis of number of players involved in rebound situations in Euroleague basketball games. Open Sports Sci J, 4(1). https://doi. org/10.2174/1875399x01104010010

Lewis, M. (2004). Moneyball: The art of winning an unfair game. WW Norton \& Company.

Luke, D. (2004). Multilevel modeling: Thousand Oaks, CA Sage.

Madarame, H. (2017). Game-Related Statistics Which Discriminate Between Winning and Losing Teams in Asian and European Men's Basketball Championships. Asian Journal of Sports Medicine, 8(2), e42727. https://doi.org/10.5812/asjsm. 42727

Navarro, R. M., Lorenzo, A., Gómez, M. Á., \& Sampaio, J. (2009). Analysis of critical moments in the league ACB 2007-08. Revista de Psicología del Deporte, 18(3), 391-395.

Ofoghi, B., Zeleznikow, J., MacMahon, C., \& Raab, M. (2013). Data Mining in Elite Sports: A Review and a Framework. Measurement in Physical Education and Exercise Science, 17(3), 171-186. https://doi.org /10.1080/1091367x.2013.805137

Oliver, D. (2004). Basketball on paper: Rules and tools for performance analysis. Dulles, VA: Brassey’s: Inc. 
Onwuegbuzie, A. (2000). Factors Associated with Success Among NBA Teams. The Sport Journal, 3(2). http://www.thesportjournal. org/2000Journal/Vol3-No2/Onwue.asp

Paulauskas, R., Masiulis, N., Vaquera, A., Figueira, B., \& Sampaio, J. (2018). Basketball game-related statistics that discriminate between European players competing in the NBA and in the Euroleague. Journal of Human Kinetics, 65, 225-233. https://doi.org/10.2478/ hukin-2018-0030

Pojskić, H., Šeparović, V., \& Užičanin, E. (2009). Differences between successful and unsuccessful basketball teams on the final Olympic tournament. Acta Kinesiologica, 3(2), 110-114.

Puente, C., Del Coso, J., Salinero, J., \& Abián-Vicén, J. (2015). Basketball performance indicators during the ACB regular season from 2003 to 2013. International Journal of Performance and Analysis in Sport, 15(3) https://doi.org/10.1080/24748668.2015.11868842

Rimler, M., Song, S., \& David, T. (2010). Estimating production efficiency in men's NCAA college basketball: A bayesian approach. Journal of Sports Economics, 11(3), 287-315. https://doi.org/10.1177/ 1527002509337803

Sáenz-López, P., Rebollo, J. A., \& Vizcaíno, C. (2017). Keys to the victory in the basketball Queen's Cup in 2016. Cuadernos de Psicología del Deporte, 17(3), 223-230.

Salmerón-Gómez, R., \& Gómez-Haro, S. (2016). Expanding horizons on performance measurement and regularity in professional basketball.
RICYDE-Revista internacional de ciencias del deporte, 12(45), 234-249. https://doi.org/10.5232/ricyde2016.04502

Sampaio, J., Godoy, S. I., \& Feu, S. (2004). Discriminative power of basketball game-related statistics by level of competition and sex. Percept Mot Skills, 99(3), 1231-1238. https://doi.org/10.2466/ pms.99.7.1231-1238

Sampaio, J., \& Janeira, M. (2003). Statistical analyses of basketball team performance: understanding team's wins and losses according to a different index of ball possessions. International Journal of Performance and Analysis in Sport, 3(1), 40-49. https://doi.org/10.1080/24748668 .2003.11868273

Srholec, M. (2010). A multilevel approach to geography of innovation. Reg Stud, 44(9), 1207-1220. https://doi.org/10.1080/00343400903365094

Teramoto, M., \& Cross, C. L. (2010). Relative importance of performance factors in winning NBA games in regular season versus playoffs. Journal of Quantitative Analysis in Sports, 6(3). https://doi. org/10.2202/1559-0410.1260

Trninić, M., Trninić, S., \& Papić, V. (2009). Development management model of elite athletes in team sports games. Collegium Antropologicum, 33(2), 363-372. https://hrcak.srce.hr/40506

Utku, M. (2016). Marginal contribution of game statistics to probability of winning at different levels of competition in basketball: Evidence from the Euroleague. International Journal of Sport Science Coaching 11(1), 98-107. https://doi.org/10.1177/1747954115624828 